\title{
Research on the Export Competitiveness of Agricultural Products in Anhui Province of China from the Low-Carbon Perspective
}

\author{
Sun Fei ${ }^{1}$, Cao Shouhui ${ }^{2 *}$ \\ ${ }^{1}$ Harbin Institute of Technology (Shenzhen) Urban and Rural Planning Postdoctoral Mobile Station, Shenzhen 518055, China \\ ${ }^{2}$ School of Business Administration, Zhongnan University of Economics and Law, Wuhan 430073, China
}

\begin{abstract}
Affected by global warming, the development of low-carbon economy in recent years has received widespread attention. In terms of trade, it is mainly manifested in carbon taxation and carbon labeling. The development of low-carbon economy will inevitably have an impact on the export of agricultural products. Taking Anhui Province, a large agricultural province in China, as an example, this paper analyzed the export competitiveness of agricultural products in Anhui by using the trade competitiveness index. The study found that agricultural export companies in Anhui had problems such as single export structure and low added value, vicious competition among export companies, and imperfect financial support systems. In order to enhance the competitiveness of agricultural exports in Anhui, the paper put forward countermeasures and suggestions in the end, such as optimizing the export structure, increasing investment in science and technology, establishing an alliance of agricultural export enterprises and increasing financial support.
\end{abstract}

\section{Introduction}

With the rapid development of the world economy and the massive emission of carbon dioxide and other greenhouse gases, the contradiction between the balanced development of the economy and the environment has become increasingly prominent, so a low-carbon economy has become an inevitable choice for future development ${ }^{[1]}$. The issue of carbon emissions hidden behind trade has begun to attract attention, and policies such as carbon tariffs have emerged as the times require, which may have an adverse impact on the competitiveness of agricultural exports in Anhui. Although the total export volume of agricultural products in Anhui has continued to grow and has achieved good scale effects, the comprehensive international competitiveness of agricultural products has fallen sharply, especially in the export of black tea and fruit, facing the dilemma of parallel growth in total volume and decline in competitiveness. The reasons are complex, including the economic structural adjustment, the reduced importance of agricultural exports in foreign trade exports by the rapid development of the manufacturing industry, and the turning point which happened to the endowment basis for the construction of the comparative advantages of agricultural products. Data from the seventh national census shows that the working-age population in China has decreased by more than 40 million in 2020, compared with that shown in the sixth census in 2010. Meanwhile, the proportion of working-age population in the total population has also declined. It is estimated that the working-age population will decrease by 35 million during the "14th Five-Year Plan" period. As a major exporter of labor, tens of millions of young and middle-aged laborers in Anhui go out to work, so the problem of agricultural labor shortage is even more serious. The structural transformation of labor supply and demand has increased wage costs and eroded the endowment basis of agricultural export competitiveness based on low wage costs. Therefore, it is necessary to question the disadvantages of the old trade growth model of "pursuing scale expansion" and consider how to reshape the competitiveness of Anhui's agricultural exports under the new situation.

The academic circle has paid great attention to the research on the international competitiveness of agricultural products in recent years. In foreign countries, Fetscherin $^{[2]}$ believed that different countries could participate in the international division of labor based on their own comparative advantages to gain competitive advantages and obtain benefits from international trade. Esterhuizen et $\mathrm{al}^{[3]}$ used the competitiveness model developed by Poter to analyze the competitiveness of agricultural export enterprises in South African, which found that competition in the land market, recent land depreciation and strict industry standards have a beneficial effect on the export competitiveness of enterprises, while the decline in the rate of capital formation has a negative impact on competitiveness. Domestically, Cheng Guoqiang ${ }^{[4]}$ studied the structural changes of China's agricultural exports from multiple perspectives, such as product structure, structure of

Corresponding author: caosh106@sina.com 
production area, export business entity and export market, and believed that the serious problem that affects the export competitiveness of China's agricultural products is that the export products are mainly primary products, and the export enterprises are small in scale. $\mathrm{Wu}$ Yang $^{[5]}$ evaluation and empirical analysis on the international competitiveness of China's agricultural products made it clear that after China's participation in the WTO, it is inevitable for to improve the international competitiveness of agricultural products in the context of increasingly fierce market competition. Zhang Lili[6] uses the CMS model to decompose the contribution of China's agricultural products to the world's three major extreme markets, including the EU, Japan, and the United States, from the perspective of demand, structure and competitiveness, which found that the contribution of structural factors to the increase in exports of the three major markets is negative, while the demand factor is still the main force in the increase in exports.

It should be noted that it is needed to study the international competitiveness of Anhui's agricultural products from the perspective of structure rather than total volume, which has indeed enriched the research in the field of competitiveness. However, the current domestic and foreign research still has the following problems. The first one is the mixed use of export competitiveness indicators of agricultural products. There are few studies on the comparison of export competitiveness indicators of agricultural products. The second one is that there is confusion and even deviation in the understanding of the connotation of agricultural product export structure, especially in the market structure of agricultural product export, which is generally understood as the regional structure of the export market. It is quite different from the connotation of the market structure in the sense of industrial organization. In view of this, this paper first gives the measurement indicators of Anhui's agricultural export competitiveness, and then makes a vertical comparison of the changes in Anhui's export competitiveness in recent years, and gives a comprehensive and threedimensional analysis of the deep reason for the decline in the export competitiveness of agricultural products in Anhui and gives specific policy recommendations.

\section{Analyses of the status Quo of Anhui's agricultural products export}

As a large agricultural province, Anhui spans the Yangtze River and the Huaihe River to the north and south. It is an important grain and oil production base in China, with 88.289 million mu (a Chinese unit of area) of arable land and an agricultural population of 25.432 million. Table 1 lists the main agricultural products and their growth rates in Anhui in 2020. It can be found that the annual grain output of Anhui in 2020 is 40.192 million tons, a decrease of $0.9 \%$ from the previous year. Among them, the output of grain and vegetables were 40.192 million tons and 23.309 million tons, respectively, an increase of $-0.9 \%$ and $5.3 \%$ over last year.
Table 1. The output and growth rate of main agricultural products in 2020 . Unit: 10,000 tons.

\begin{tabular}{|c|c|c|}
\hline $\begin{array}{c}\text { Product } \\
\text { Name }\end{array}$ & $\begin{array}{c}\text { Absolute } \\
\text { Number }\end{array}$ & YoY (\%) \\
\hline Gain & 4019.2 & -0.9 \\
\hline Oil & 162.5 & 0.7 \\
\hline Peanuts & 72.3 & 2.5 \\
\hline Rapeseed & 85.3 & -2.3 \\
\hline Cotton & 4.1 & -26.2 \\
\hline $\begin{array}{c}\text { Flue-Cured } \\
\text { Tobacco }\end{array}$ & 2.0 & 13.5 \\
\hline Tea & 12.9 & 5.4 \\
\hline Vegetable & 2330.9 & 5.3 \\
\hline Fruit & 741.5 & 5.0 \\
\hline
\end{tabular}

Source: "Statistical Bulletin of Anhui's National Economic and Social Development in 2020".

A further analysis of the import and export status of Anhui and the import and export of agricultural products is shown in Table 2 and Figure 1. It can be found that the average contribution rate of the import and export of agricultural products in Anhui to the total import and export was $9.19 \%$ and $5.73 \%$ from 2010 to 2019 . During the same period, the total import and export volume of agricultural products in Anhui showed a steady upward trend, reaching US\$5.295 billion. However, the export value of agricultural products was higher than the import value before 2015, while the import value began to surpass after that, in order words, the net export value went from positive to negative, indicating that Anhui's agricultural products gradually began to rely on imports. In addition, the net export of agricultural products in Anhui reached a peak of US\$515 million in 2011, and then the trade deficit began to appear and rapidly expanded. By 2019, the trade deficit reached US\$1.31 billion.

Table 2. The total import and export volume of Anhui and agricultural products from 2010 to 2019 . Unit: 100 million \$.

\begin{tabular}{|c|c|c|c|c|}
\hline \multirow{2}{*}{ Year } & \multicolumn{2}{|c|}{ Export Value } & \multicolumn{2}{c|}{ Import Value } \\
\cline { 2 - 5 } & $\begin{array}{c}\text { Export } \\
\text { Value }\end{array}$ & $\begin{array}{c}\text { Export } \\
\text { Contri- } \\
\text { bUtion } \\
\text { Rate }\end{array}$ & $\begin{array}{c}\text { Import } \\
\text { Value }\end{array}$ & $\begin{array}{c}\text { Conport } \\
\text { bution } \\
\text { Rate }\end{array}$ \\
\hline 2010 & 6.56 & 5.28 & 4.50 & 3.79 \\
\hline 2011 & 13.42 & 7.86 & 8.27 & 5.80 \\
\hline 2012 & 15.36 & 5.74 & 11.55 & 9.19 \\
\hline 2013 & 16.50 & 5.84 & 16.41 & 9.45 \\
\hline 2014 & 17.38 & 5.52 & 15.72 & 8.84 \\
\hline 2015 & 16.43 & 4.96 & 15.20 & 9.68 \\
\hline 2016 & 15.76 & 5.53 & 19.24 & 12.10 \\
\hline 2017 & 18.32 & 6.01 & 24.27 & 10.48 \\
\hline & & & & \\
\hline
\end{tabular}




\begin{tabular}{|l|l|l|l|l|}
\hline 2018 & 20.50 & 5.66 & 29.33 & 10.96 \\
\hline 2019 & 19.92 & 4.93 & 33.03 & 11.66 \\
\hline
\end{tabular}

Note: Contribution Rate of Imports (Exports) = Total Imports (Exports) Value of Agricultural Products / Total Imports (Exports) Value of Anhui.

Source: "Anhui Statistical Yearbook (2011-2020)".

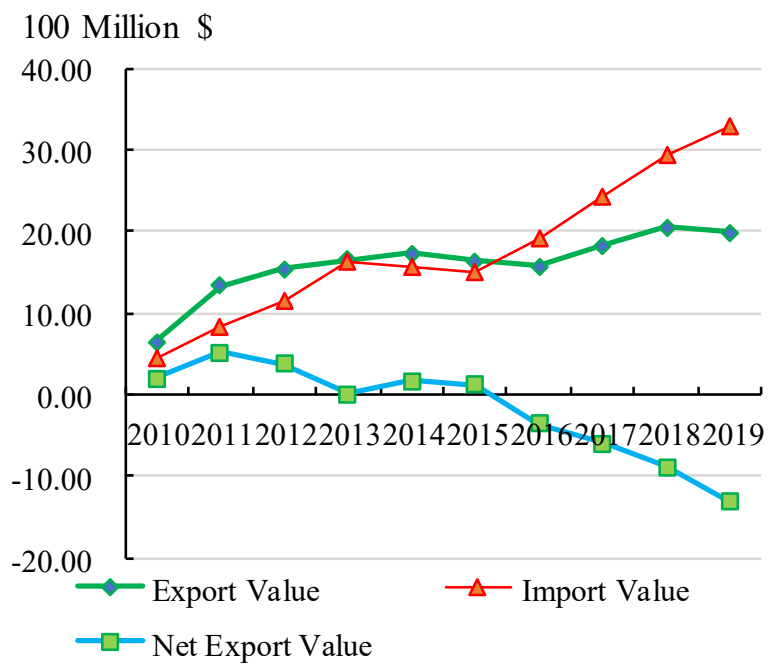

Fig. 1. The run chart of the import and export trade volume of agricultural products in Anhui from 2010 to 2019.

Note: Net Export Value $=$ Total Export Value of Agricultural Product Export-Total Import Value of Agricultural Product. Source: “Anhui Statistical Yearbook (2011-2020)".

\section{Measure of agricultural product export competitiveness in Anhui}

The export competitiveness of agricultural products is affected by many factors. Therefore, domestic and foreign scholars have put forward various types of indicator systems and measurement models when analyzing and measuring the export competitiveness of a country or region. This article mainly uses the trade competitiveness index to measure according to the specific research content.

The trade competitiveness index (also known as the $\mathrm{TC}$ index) refers to the proportion of the net export of a certain product of a country or region in the total import and export trade of the product, which is a common tool for measuring the international competitiveness of the industry. Compared with the net export index, the trade competitiveness index excludes the influence of inflation and other external economic environment fluctuations, and takes into account the two factors of import and export, with its value between $(-1,1)$, which is widely comparable between different countries and different periods. The calculation formula is as follows:

$$
T C_{i j}=\left(X_{i j}-M_{i j}\right) /\left(X_{i j}+M_{i j}\right)
$$

Where, $X_{i j}$ represents the total export volume of products of category $\mathrm{j}$ in country $\mathrm{i}, M_{i j}$ represents the total volume import volume of category $\mathrm{j}$ in country $\mathrm{i}$, with the value of $T C_{i j}$ varies between 1 and -1 . If $T C_{i j}=0$, it means that the export competitiveness of $\mathrm{j}$ products in country $\mathrm{i}$ is at the international average level. Product differences may lead to the imports and exports of products $\mathrm{j}$ in country $\mathrm{i}$. If $T C_{i j}>0$, products $\mathrm{j}$ in country $\mathrm{i}$ have strong export competitiveness. Compared with the world market, country $i$ is a net provider of $j$ products. If $T C_{i j}<0$, it means that the product is less competitive. The closer the $T C_{i j}$ is to 1 , the stronger the international competitiveness of the product. The closer $T C_{i j}$ is to -1 , the weaker the export competitiveness of the product $j$ in country, which means that country $i$ is the pure demander of product $\mathrm{j}$.

According to the measurement method of trade competitiveness and related data, this paper measures the agricultural trade competitiveness index (TC) of Anhui from 2010 to 2019, as shown in Figure 2. The overall competitiveness index of agricultural product trade in Anhui showed a downward trend from 2010 to 2019. Although there was a slight increase in fluctuations between 2013 and 2015, reaching 0.04, it fell to a negative value after 2015 and has been in a downward state, reaching -0.25 in 2019 . It is generally believed that the closer the trade competitiveness index (TC) is to -1 , the weaker international competitiveness. Therefore, it can be seen that the competitiveness of agricultural exports in Anhui is generally weak and has a tendency to deteriorate in recent years.

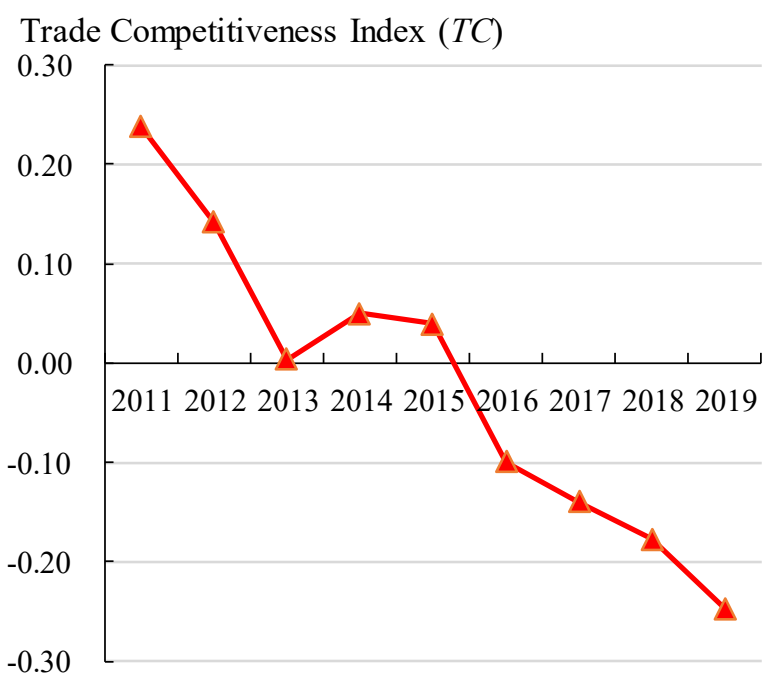

Fig. 2. Agricultural products trade competitiveness index in Anhui from 2010 to 2019.

\section{Problems Existing in the Export of Agricultural Products in Anhui}

\subsection{The export structure is single and the added value is low}

The export of agricultural products in Anhui mainly relies on products such as primary grain, tea, Chinese medicinal materials, honey and other products with low value-added and poor brand effect, while the proportion of deep-processed, high-tech, high-value-added agricultural products is relatively low. In addition, agricultural products in Anhui are also facing the problem of a single export structure. Anhui needs to 
make more efforts in developing emerging markets, if it wants to realize the diversification and global development of agricultural exports. The base trade method is single. The agricultural products exported from the Anhui base are mainly based on general trade, with less other trade methods, due to the slow development of the deep processing industry of agricultural products in Anhui, and large number of agricultural product processing enterprises in the base, with small scale. Moreover, the processing of agricultural products in Anhui is mainly primary products and semi-processed products, and the cost of processed bulk agricultural products is relatively high, which have led to the fact that the agricultural products exported by Anhui agricultural bases are still dominated by general trade. Furthermore, the export of agricultural products in Anhui faces the problem that its agriculture mainly relies on and consumes the advantages of local resources, which is prone to price or green trade barriers, and lack of sustainability.

\subsection{Vicious Competition from Export Companies}

A large number of small and medium-sized enterprises are the main body of agricultural exports in Anhui, while the number of key leading enterprises is small, with less driving scope. Agricultural products in Anhui lack influential brands in the international market. Many companies, including the base, mainly produce OEM products. Most of the base' $s$ export products don' $t$ have their own brands. In addition, due to the lack of independent brands and homogenization of products, a large number of enterprises have caused fierce and even vicious competition, making it difficult to go global. The existing production areas of famous brand agricultural products are mainly concentrated in the advantageous agricultural product layout belt of Anhui, with relatively low market popularity and market share of agricultural products that have obtained provincial-level brands. Although some exported agricultural products have brands, the lack of unified logos and insufficient publicity have led to low brand awareness, which is difficult to form an internationally renowned "Anhui specialty" in the field of agricultural products like Heilongjiang rice, Jilin ginseng, and Shanxi grains.

\subsection{Imperfect Financial Support System}

Financing difficulties are currently the main factor restricting the development of many small- and mediumsized enterprises of agricultural export. The formal credit threshold is relatively high, and agricultural land or agricultural infrastructure owned by agricultural enterprises can' $t$ be used as collateral for loans. In addition, most of the agricultural export enterprises in Anhui have small business scales and poor profitability. Therefore, the financial industry is cautious and reluctant to take loans in order to risk avoidance, and insufficient capital services have caused shortage of funds and financing difficulties that have long plagued agricultural export enterprises. The lack of sufficient development funds makes agricultural export companies passive in terms of expansion and development, talent introduction, technological and equipment transformation, and new product development, forcing agricultural product processing companies to only carry out small-scale and simple rough processing for a long time. Moreover, the current agricultural insurance and export credit insurance systems in Anhui are imperfect, and the export risk of agricultural products is relatively high, which ultimately leads to the formation of "bad" path dependence and a vicious circle for agricultural product processing enterprises.

\section{Conclusion}

Based on the analysis of the current situation of import and export of agricultural products in Anhui Province, this paper measures the trade competitiveness of agricultural products by using the trade competitiveness index, and draws the following conclusions: (1) The total import and export of agricultural products in Anhui Province showed a steady rising trend from 2010 to 2019 , but after 2015, the import volume obviously exceeded the export volume, and the trade deficit began to appear and continued to expand. (2) Through the measurement of competitiveness index, it can be found that in recent years, the export competitiveness of agricultural products in Anhui Province is generally weak and has a worsening trend. (3) Anhui agricultural products trade export structure is single, low added value, serious consumption of local resources, lack of sustainability, at the same time, agricultural products brand awareness is not high, the lack of financial support is not conducive to the development of low-carbon trade.

The research of this paper has the following implications for improving the competitiveness of agricultural products in Anhui Province and formulating trade policies in line with low-carbon development:

(1) Optimization of export structure and increase of investment in science and technology. The advantage of land-intensive agricultural products in Anhui is relatively weak. Although grain and oil agricultural products have shown a strong growth momentum, their exports have weakened due to the reduction in the area of arable land. According to the principle of benefit first, the production of low-quality rice should be appropriately reduced, the cultivation of high-quality rice should be increased, and the formation of an appropriate scale of agricultural operation should be continuously promoted. At the same time, it can make full use of the local agricultural product culture in Anhui to improve the influence, competitiveness and brand value of characteristic agricultural products. Enterprises must continuously improve their technical level and increase the added value of agricultural products. It is needed to seize the opportunity to develop organic food and green food with high technology as the forerunner, actively introduce, promote and apply high technology to transform traditional processing methods, vigorously develop Anhui's intensive processing of agricultural products, so 
as to increase the added value of agricultural exports in Anhui and enhance its export competitiveness.

(2) Establishing an alliance of agricultural export enterprises. Powerful multinational companies are currently the main contenders for international competitiveness. Therefore, Anhui should focus on supporting a group of agricultural products export enterprises with investment potential and accelerate the realization of the "going out" strategy of agricultural products enterprises. Specifically, the existing organizational form can be reformed, the industrialization alliance can be implemented, the alliance enterprises can be cultivated to organize the scattered small farmers to produce, and the "company + base + farmers" approach can be adopted to improve their competitiveness, which is also conducive to the collection of market information and rapid response to the market. Meanwhile, it can also be linked with local characteristic agriculture, relying on key export enterprises and establishing alliances of agricultural product export enterprises, forming scale advantages, and creating agricultural products cluster characteristic brands with international influence. It is required to create and cultivate the agricultural export brand of Anhui, accelerate the integration into the "One Road, One Belt" strategy, establish a production and marketing consortium through strategic alliances and strategic alliances, create and form the core competitiveness of the enterprise, and promote the development of economies of scale and the international reputation of agricultural products in Anhui.

(3) Increase financial support. The relationship between banks and enterprises directly determines the financing quality of enterprises. Therefore, governments at all levels in Anhui should actively play the role of bridges and bonds to build a bank-enterprise docking platform and agricultural product credit insurance platform to encourage financial institutions to expand the scale of credit insurance business for agricultural product export enterprises and give preferential interest rates. Government should provide support in terms of policies and financial funds, recruit and cultivate a group of highquality science and technology talents of new agricultural, and continuously develop new technologies and products to become the core competitiveness of enterprises. The government can also provide necessary financial support in conjunction with financial institutions. For example, to provide tea companies with financing and turnover through preferential loans, etc., to alleviate the financial difficulties of tea companies, and to ensure the technological innovation and trade development of tea companies. At the same time, the government can formulate tax reduction policies and provide technical training and technical guidance to farmers to increase the enthusiasm of farmers and exporters. Besides, as the three strategic implementation bases of "Rise of Central China", "Yangtze River Economic Belt" and "Wanjiang City Belt" and an important node of "One Belt One Road", Anhui should increase investment attraction and actively attract foreign capital to inject capital into agricultural export enterprises.

\section{References}

1. X.X. Li, X. Feng, Strengthening Climate Quality Certification and Improving the Export Quality of Agricultural Products, International Trade, 7, 32-37 (2016)

2. M. Fetscherin, I. Alon, P. Johnson, James, Assessing the Export Competitiveness of Chinese Industries, Asian Business \& Management,9,401-424 (2010)

3. D. Esterhuizen, J.V. Rooyen, Determination of Competitiveness of South African Agricultural Export Firms, Competitiveness Reviews, 16, 223233 (2006)

4. G.Q. Cheng, Improvement of Export Competitiveness: Changes in the Export Structure of China's Agricultural Products and Policy Recommendations, International Trade, 2, 17-21 (2004)

5. Y. Wu, Evaluation and Empirical Analysis of the International Competitiveness of China's Agricultural Products, International Business (Journal of University of International Business and Economics), 1, 48-53 (2007)

6. L.L. Zhang, Analysis of Export Structure and Competitiveness of Agricultural Product: A Comparative Study Based on European, American and Japanese markets, International Trade, 12, 15$16(2011)$ 